\title{
Dökümhanelerde İş Sağlığı Güvenliği Uygulamaları: Örnek Bir Uygulama
}

\author{
Occupational Health and Safety Practices in Foundries: A Case Study
}

\author{
Pınar YEŞiLGÖZ, Hüseyin ADANIR
}

\begin{abstract}
ÖZET
Bu çalışmada, İstanbul ilinde dökümhanelerde çalışan 150 kişi ile anket çalışması yapılmıştır. Anket çalışmasında dökümhanelerde çalışanların yaşları, demografik özellikleri, kişisel koruyucu donanım kullanıp kullanmadıkları, çalışma süresince karşılaşılan olumsuz faktörler, çalışma koşullarına bağlı geçirilen hastalıklar, çalışma ortamında maruz kalınan fiziksel faktörler, iş güvenliği eğitimleri alıp almadıkları, en çok iş kazası geçirilen bölüm ve iş kazalarına uğrama nedenlerine yönelik veriler istatistiki olarak irdelenmiştir. Ankete verilen cevaplar değerlendirildiğinde elde edilen sonuçlar gerekse iş kazası istatistikleri iş sağlığı ve güvenliği çalışmalarının ülkemizde henüz istenen düzeye ulaşmadığını göstermektedir.
\end{abstract}

Anahtar Kelimeler: İș Kazası, İș Güvenliği, Dökümhane, Çalışanlar

\section{ABSTRACT}

In this study, a survey was carried out to 150 people working in foundries in Istanbul. In questionnaire study searched demographic characteristics of workers, their use of personal protective equipment and attitudes, immortal factors encountered during the study, illnesses related to working conditions, physical factors exposed in working enviroment, occupational security tranings and reasons for job accidents. When the answers to the questionnaire are evaluated, the results of the work accident statics show that the occupational health and safety studies have not reached the desired levels in our country.

Keywords: Work Accident, Occupational Safety, Foundry, Employees

Pınar YEŞiLgÖZ - Marmara Üniversitesi, Fen Bilimleri Enstitüsü, İş Güvenliği Anabilim Dalı, İstanbul, Türkiye

Pinar YESILGOZ - Marmara University, Institute of Pure and Applied Sciences, Occupational Safety Department, Istanbul, Turkey yslgz.pnr@gmail.com

Dr. Öğr. Üyesi Hüseyin ADANIR - Marmara Üniversitesi, Mühendislik Fakültesi, Malzeme Müh. Bölümü, İstanbul, Türkiye Assist. Prof. Dr. Huseyin ADANIR - Marmara University, Engineering Faculty, Metallurgical and Materials Engineering, Istanbul, Turkey huseyin.adanir@marmara.edu.tr 


\section{GIIRIŞ}

Döküm ürünleri birçok sanayi dalında girdi olarak kullanılması nedeniyle dökümcülük imalat sanayisinde önemli bir yere sahiptir. Döküm sektörü, gelişen sanayi ve ilerleyen teknolojiyle makineleşme yolunda ilerlemesine rağmen yoğun emek gerektiren bir sanayi koludur. Hızlı sanayileşme ve ilerleyen teknoloji ile beraber iş kazaları dünyada ve ülkemizde önemli bir sorun oluşturmaktadır. Metal iş kolunda yer alan döküm sektöründe iş kazası riski yüksek olup ciddi boyutlarda iş kazaları yaşanmaktadır.

İşyerinde çalışma koşullarının meydana getirdiği, çalışanlara, makine ve tesislere veya üretime yönelik tehlike, zarar ve aksaklıkların araştırılması ve önlenmesi bakımından yapılan metotlu çalışmalara "iş güvenliği denir [1].

1950 yılında ILO (Uluslararası Çalışma Örgütü) ve WHO (Dünya Sağlık Örgütü) nün oluşturduğu ortak bir komisyonda ve ILO'nun 112 sayılı Tavsiye kararında iş sağlığının amaçlarını şu başlıklar altında "çalışanların sağlık kapasitelerini en yüksek düzeye çıkarmak”, “çalışmanın olumsuz koşulları nedeni ile sağlığın bozulmasını önlemek", "her iş̧̧iyi fiziksel ve ruhsal yeteneklerine uygun işlerde çalıştırmak" ve "yapılan iş ile işçi arasında uyum sağlayarak, en az yorgunlukla verim elde etmek" şeklinde tanımlanmıştır. 5510 sayılı Sosyal Sigortalar ve Genel Sağlık Sigortası Kanunu'nun 13. Maddesine göre

"İş kazası;

a) Sigortalının işyerinde bulunduğu sırada,

b) İşveren tarafından yürütülmekte olan iş nedeniyle veya görevi nedeniyle, sigortalı kendi adına ve hesabına bağımsız çalışıyorsa yürütmekte olduğu iş veya çalışma konusu nedeniyle işyeri dışında,

c) Bir işverene bağlı olarak çalışan sigortalının, görevli olarak işyeri dışında başka bir yere gönderilmesi nede- niyle asıl işini yapmaksızın geçen zamanlarda,

d) Emziren kadın sigortalının, çocuğuna süt vermek için ayrılan zamanlarda,

e) Sigortalıların, işverence sağlanan bir taşıtla işin yapıldığı yere gidiş gelişi sırasında, meydana gelen ve sigortalıyı hemen veya sonradan bedenen ya da ruhen özre uğratan olaydır.”

İş kazalarının nedenleri araştırıldığında yaklaşık \% 80 'nin insan faktörüne, \%20'sinin ise çevre, makine ve ekipman faktörlerine bağlı olarak ortaya çıkmış olduğu görülmüştür [2]. Eğitim faktörü önemli bir etken olup ABD'de yapılan araştırmalar sonucunda, çalışanlara eğitim çalışmalarının yapılması ve uygun ortamların yaratılması durumunda kazaların \%97’sinin önlenebileceği saptanmış$\operatorname{tir}[3]$.

Meslek hastalığı, 5510 sayılı Sosyal Sigortalar ve Genel Sağlık Sigortası Kanununun 14. maddesinde “sigortalının çalıştığı veya yaptığı işin niteliğinden dolayı tekrarlanan bir sebeple veya işin yürütüm şartları yüzünden uğradığı geçici veya sürekli hastalık, bedensel veya ruhsal engellilik halleri” olarak tanımlanmaktadır.

Toz, metal buharı, gürültü, yüksek 1sı, gazlar gibi riskler nedeniyle dökümhaneler riskli koşullara sahiptir[4]. Döküm sektörü, büyük boyutlarda malzemelerin taşınması, yüksek sıcaklıklardaki erimiş metaller, toz, gürültü, termal konfor koşulları, hijyen, gürültü, aşındırıcı maddeler vb. gibi çok sayıda riski içermektedir [5].

İşyeri ortamında bulunan bazı fiziksel faktörler, meslek hastalıklarına sebep olmaktadır. Fiziksel etmenlerin neden olduğu en çok görülen meslek hastalıkları, gürültüye bağlı işitme kaybı, sıcak ve soğuk ortamlarda çalışanlarda görülen meslek hastalıkları, iyonlaşan ve iyonlaşmayan radyasyonun etkilerine bağlı hastalıklar, titreşim etkisi ve tekrarlı işlemler nedeniyle meydana gelen hastalıklardan 
oluşmaktadır [6].

Dökümhanelerde kalıp hazırlama sistemleri, taşlama, temizleme işlemleri ve titreşimle çalışan ağır makineler gürültünün kaynaklarıdır. Dökümhanelerde tespit edilen gürültü düzeyleri yüksektir. Bu nedenle dökümhane çalışanlarında gürültüye bağlı olarak işitme kayıpları sık rastlanılan bir sağlık sorunudur. Dökümhanelerde, gürültünün azaltılması için mühendislik yöntemleri kullanılarak yapılan çalışmalara ihtiyaç duyulmaktadır [7] .

İşyerlerinde çalışma ortamlarındaki termal konfor şartları, çalışanları fiziksel ve psikolojik yönden olumsuz etkilememelidir [8]. Çalışma ortamı sıcaklığı çalışanların harcadıkları güce ve çalışma şekline uygun olmalıdır. Dökümhanelerde ergitme işlemi sırasında indüksiyon ocağının yüksek sıcaklığı ve ergimiş metalin potaya aktarılması esnasında ortama yayılan ısı nedeniyle çalışanlar yüksek ısı riskine maruz kalmaktadır. Çalışma ortamlarının sıcak olması, hava akımının olmaması, kalın ve sentetik kıyafetler gibi nedenlerden dolayı çalışanlar olumsuz etkilenmekte ve çalışanlar ısı çarpmasına maruz kalmaktadır [9] .

İşyeri havalandırmasının çalışanların sağlıkları ve çalışma performansı üzerinde önemli etkisi vardır. Çalışma ortamında ortaya çıkan gaz, buhar ve toz işyerinin havasını kirletir. Çalışma ortamındaki kirli hava, çalışanların yeterli oksijen alamamalarına neden olur. Bunun sonucunda çalışanların duyarlılıkları olumsuz yönde etkilenerek iş kazalarının meydana gelmesine yol açmaktadır [10].

Dökümhanelerde elle taşınan potalarda yüksek miktarlarda çıkarılan küçük boyutlu malzemelerin dökümü sırasında çalışanların eğilmesi ve taşınan potaların ağırlığı çalışanlar açısından ergonomik risk oluşturmaktadır [11].

İşyerinde yeterli düzeyde aydınlatma, çalışanlar üzerinde olumlu psikolojik etkiler yaratır. Yetersiz aydınlatma olması durumunda ise çalışanlarda göz ve vücut yorgunlu- ğu oluşur. Yapılan bir araştırmada; işyerindeki ışık şiddetinin 50 lüks' ten 200 lüks' e çıkarılması halinde kaza oranının \%32' ye düştüğü saptanmıştır. Aynı işyerinin duvarlarının açık ve yansıtıcı bir renkle boyandıktan sonra kaza oranlarında \%6,5'lik bir azalma daha olduğu görülmüştür [12].

\section{MALZEME VE METOT}

$\mathrm{Bu}$ çalışmada, dökümhanelerde iş sağlığı ve güvenliği uygulamalarının mevcut durumunun analizi yapılmış ve bu uygulamaların yeterli olup olmadığı incelenmiştir. Araştırma, İstanbul ilinde faaliyet göstermekte olan dökümhanelerde seçilen örnek gruba anket uygulaması şeklinde yapılmıştır. Ankette yer alan sorulara verilen cevapların güvenilirliğini sağlamak amacıyla çalışanların kimliklerini ortaya çıkartacak sorulara yer verilmemiştir. Dökümhanelerde iş sağlığı ve güvenliği uygulamalarının ne düzeyde uygulandığının SPSS 24 programı kullanılarak incelenmiştir.

Ankette çalışanların yaşları ve cinsiyetleri, eğitim düzeyleri, çalışılan bölüm, çalışma süreleri, dökümhanede iş kazası geçirip geçirmedikleri, dökümhanede meydana gelen iş kazaları sıklık oranı, dökümhanede iş kazası geçirilen bölüm, dökümhanede iş kazalarının nedeni, çalışma ortamının iş sağılığı ve güvenliği açısından uygun olup olmadığ1, dökümhanede çalışmayı olumsuz yönde etkileyen faktörler, çalışma ortamında gerekli kişisel koruyucu donanımlara sahip olup olmadığı, sahip olduğu halde kullanılıp kullanılmaması, kişisel koruyucu donanımların kullanımına özen gösterilmemesinin nedeni, dökümhanede çalışmadan dolayı sağlıkla ilgili yapılan en fazla şikayet ve iş sağlığı ve güvenliği eğitimi alınıp alınmaması soruları sorulmuştur. 


\section{BULGULAR}

Tablo 1: Çalışanların yaşlarına göre dağılımı

\begin{tabular}{|c|c|c|c|c|}
\hline \multicolumn{2}{|c|}{} & Frekans & $\begin{array}{c}\text { Yüzde } \\
(\%)\end{array}$ & $\begin{array}{c}\text { Kümülatif } \\
\text { Yüzde } \\
(\%)\end{array}$ \\
\hline \multirow{4}{*}{ Yaş } & $18-25$ & 4 & 2,7 & 2,7 \\
\cline { 2 - 5 } & $26-29$ & 17 & 11,3 & 14 \\
\cline { 2 - 5 } & $30-35$ & 35 & 23,3 & 37,3 \\
\cline { 2 - 5 } & $36-45$ & 62 & 41,3 & 78,7 \\
\cline { 2 - 5 } & $45-55$ & 31 & 20,7 & 99,3 \\
\cline { 2 - 5 } & $55-$ & 1 & 0,7 & 100 \\
\cline { 2 - 5 } & Toplam & 150 & 100 & \\
\hline
\end{tabular}

Tablo 2: Çalışanların eğitim düzeylerine göre dağılımı

\begin{tabular}{|c|c|c|c|c|}
\hline \multicolumn{2}{|c|}{} & Frekans & Yüzde (\%) & $\begin{array}{c}\text { Kümülatif } \\
\text { Yüzde } \\
(\%)\end{array}$ \\
\hline \multirow{4}{*}{$\begin{array}{c}\text { Eğitim } \\
\text { düzeyi }\end{array}$} & Illöğretim & 31 & 20,7 & 20,7 \\
\cline { 2 - 5 } & Ortaöğretim & 65 & 43,3 & 64 \\
\cline { 2 - 5 } & Lise & 46 & 30,7 & 94,7 \\
\cline { 2 - 5 } & Üniversite & 8 & 5,3 & 100 \\
\cline { 2 - 5 } & Toplam & 150 & 100 & \\
\hline
\end{tabular}

Tablo 3: Çalıştıkları bölüme göre dağılımları

\begin{tabular}{|c|c|c|c|c|}
\hline \multicolumn{2}{|c|}{} & Frekans & $\begin{array}{c}\text { Yüzde } \\
\text { (\%) }\end{array}$ & $\begin{array}{c}\text { Kümülatif } \\
\text { Yüzde } \\
(\%)\end{array}$ \\
\hline \multirow{6}{*}{$\begin{array}{c}\text { Kum } \\
\text { hazırlama }\end{array}$} & 8 & 5,3 & 5,3 \\
\cline { 2 - 5 } & $\begin{array}{c}\text { Maça } \\
\text { yapımı }\end{array}$ & 26 & 17,3 & 22,7 \\
\cline { 2 - 5 } & Kalıp yapımı & 34 & 22,7 & 45,3 \\
\cline { 2 - 5 } & $\begin{array}{c}\text { Eritme } \\
\text { ocağı }\end{array}$ & 13 & 8,7 & 54 \\
\cline { 2 - 5 } & Döküm & 65 & 43,3 & 97,3 \\
\cline { 2 - 5 } & Diğer & 4 & 2,7 & 100 \\
\cline { 2 - 5 } & Toplam & 150 & 100 & \\
\hline
\end{tabular}

Tablo 4: Dökümhane çalıșanlarının kıdem süreleri

\begin{tabular}{|c|c|c|c|c|}
\hline \multicolumn{2}{|c|}{} & Frekans & $\begin{array}{c}\text { Yüzde } \\
(\%)\end{array}$ & $\begin{array}{c}\text { Kümülatif } \\
\text { Yüzde } \\
(\%)\end{array}$ \\
\hline \multirow{4}{*}{$\begin{array}{c}\text { Deneyim } \\
\text { Süresi }\end{array}$} & $0-5$ & 45 & 30 & 30 \\
\cline { 2 - 6 } & $5-10$ & 60 & 40 & 70 \\
\cline { 2 - 6 } & $10-15$ & 30 & 20 & 90 \\
\cline { 2 - 6 } & $15-20$ & 9 & 6 & 96 \\
\cline { 2 - 6 } & 20 yıldan & 6 & 4 & 100 \\
\cline { 2 - 6 } & \begin{tabular}{c} 
Toplam \\
\cline { 2 - 5 }
\end{tabular} & 150 & 100 & \\
\hline
\end{tabular}

Tablo 5: Çalışanların iş kazası geçirme

\begin{tabular}{|c|c|c|c|c|}
\hline & & Frekans & $\begin{array}{l}\text { Yüzde } \\
\text { (\%) }\end{array}$ & $\begin{array}{c}\text { Kümülatif } \\
\text { Yüzde } \\
(\%)\end{array}$ \\
\hline & Evet & 42 & 28 & 28 \\
\hline İs kazası & Hayır & 44 & 29,3 & 57,3 \\
\hline $\begin{array}{l}\text { geçırme } \\
\text { durumları }\end{array}$ & $\begin{array}{c}\text { Geçiren } \\
\text { birine şahit } \\
\text { olunması }\end{array}$ & 64 & 42,7 & 100 \\
\hline & Toplam & 150 & 100 & \\
\hline
\end{tabular}

Tablo 6: Dökümhanede meydana gelen iş kazalarının sıklık oranı

\begin{tabular}{|c|c|c|c|c|}
\hline \multicolumn{2}{|c|}{} & Frekans & $\begin{array}{c}\text { Yüzde } \\
(\%)\end{array}$ & $\begin{array}{c}\text { Kümülatif } \\
\text { Yüzde } \\
(\%)\end{array}$ \\
\hline \multirow{4}{*}{$\begin{array}{c}\text { İş kazaları } \\
\text { sıklık oranı }\end{array}$} & $\begin{array}{c}\text { Hiçbir } \\
\text { zaman }\end{array}$ & 36 & 24 & 24 \\
\cline { 2 - 5 } & Ara sıra & 58 & 38,7 & 62,7 \\
\cline { 2 - 5 } & Sık sık & 16 & 10,7 & 73,3 \\
\cline { 2 - 5 } & Çoğunlukla & 38 & 25,3 & 98,7 \\
\cline { 2 - 5 } & Her zaman & 2 & 1,3 & 100 \\
\cline { 2 - 5 } & Toplam & 150 & 100 & \\
\hline
\end{tabular}


Tablo 7: Dökümhanede iş kazası geçirilen bölüm veya şahit olunan bölüm

\begin{tabular}{|c|c|c|c|c|}
\hline \multicolumn{2}{|c|}{} & Frekans & $\begin{array}{c}\text { Yüzde } \\
(\%)\end{array}$ & $\begin{array}{c}\text { Kümülatif } \\
\text { Yüzde } \\
(\%)\end{array}$ \\
\hline \multirow{4}{*}{ Bölüm } & $\begin{array}{c}\text { Kum } \\
\text { hazırlama }\end{array}$ & 2 & 1,9 & 1,9 \\
\cline { 2 - 5 } & $\begin{array}{c}\text { Maça } \\
\text { yapımı }\end{array}$ & 15 & 14,2 & 16 \\
\cline { 2 - 5 } & Kalıp yapımı & 24 & 22,6 & 38,7 \\
\cline { 2 - 5 } & $\begin{array}{c}\text { Eritme } \\
\text { ocağı }\end{array}$ & 10 & 9,4 & 48,1 \\
\cline { 2 - 5 } & Döküm & 55 & 51,9 & 100 \\
\cline { 2 - 5 } & Toplam & 106 & 100 & \\
\hline
\end{tabular}

Tablo 8: Dökümhane çalışma ortamının iş sağlığı ve güvenliği açısından uygun bulma durumları

\begin{tabular}{|c|c|c|c|c|}
\hline \multicolumn{2}{|c|}{} & Frekans & $\begin{array}{c}\text { Yüzde } \\
(\%)\end{array}$ & $\begin{array}{c}\text { Kümülatif } \\
\text { Yüzde } \\
(\%)\end{array}$ \\
\hline \multirow{3}{*}{$\begin{array}{c}\text { İş Güvenliği } \\
\text { Uygunluğu }\end{array}$} & Evet & 68 & 45,3 & 45,3 \\
\cline { 2 - 5 } & Hayır & 82 & 54,7 & 100 \\
\cline { 2 - 5 } & Toplam & 150 & 100 & \\
\hline
\end{tabular}

Tablo 9: Dökümhanede yaşanan iș kazasının nedenleri

\begin{tabular}{|c|c|c|c|c|}
\hline & & Frekans & $\begin{array}{c}\text { Yüzde } \\
(\%)\end{array}$ & $\begin{array}{l}\text { Kümülatif } \\
\text { Yüzde } \\
(\%)\end{array}$ \\
\hline \multirow{11}{*}{$\begin{array}{l}\text { Dökümhanede } \\
\text { iş kazasının } \\
\text { nedeni }\end{array}$} & $\begin{array}{c}\text { İş arkadaşlarıyla } \\
\text { yapılan güvensiz } \\
\text { hareketler }\end{array}$ & 5 & 3,3 & 3,3 \\
\hline & $\begin{array}{l}\text { Dikkatsiz } \\
\text { çalışma }\end{array}$ & 7 & 4,7 & 8 \\
\hline & $\begin{array}{l}\text { Donanımı } \\
\text { güvensiz } \\
\text { kullanma }\end{array}$ & 6 & 4 & 12 \\
\hline & $\begin{array}{l}\text { Kusurlu alet ve } \\
\text { ekipman vb. }\end{array}$ & 42 & 28 & 40 \\
\hline & $\begin{array}{l}\text { Kişisel koruyucu } \\
\text { donanımların } \\
\text { uygun olmaması }\end{array}$ & 19 & 12,7 & 52,7 \\
\hline & $\begin{array}{c}\text { Kişisel koruyucu } \\
\text { donanımların } \\
\text { verilmemesi }\end{array}$ & 3 & 2 & 54,7 \\
\hline & $\begin{array}{l}\text { Eğitim yeter- } \\
\text { sizliği }\end{array}$ & 13 & 8,7 & 63,3 \\
\hline & $\begin{array}{c}\text { Denetim yeter- } \\
\text { sizliği }\end{array}$ & 28 & 18,7 & 82 \\
\hline & $\begin{array}{c}\text { İş yükü fazlalığı/ } \\
\text { yorgunluk }\end{array}$ & 17 & 11,3 & 93,3 \\
\hline & Diğer & 10 & 6,7 & \\
\hline & Toplam & 150 & 100 & 100 \\
\hline
\end{tabular}

Tablo 10: Dökümhanede çalışma ortamını olumsuz yönde etkileyen faktörlerin dağılımı

\begin{tabular}{|c|c|c|c|c|}
\hline & & Frekans & $\begin{array}{l}\text { Yüzde } \\
(\%)\end{array}$ & $\begin{array}{c}\text { Kümülatif } \\
\text { Yüzde } \\
(\%)\end{array}$ \\
\hline \multirow{8}{*}{$\begin{array}{l}\text { Dökümha- } \\
\text { nede } \\
\text { çalışma } \\
\text { ortamını } \\
\text { olumsuz } \\
\text { yönde } \\
\text { etkileyen } \\
\text { faktörler }\end{array}$} & $\begin{array}{c}\text { Gürültünün fazla } \\
\text { olması }\end{array}$ & 23 & 15,3 & 15,3 \\
\hline & Aşırı sıcaklık & 49 & 32,7 & 48 \\
\hline & Toz & 46 & 30,7 & 78,7 \\
\hline & $\begin{array}{c}\text { Havalandırma } \\
\text { Yetersizliği }\end{array}$ & 15 & 10 & 88,7 \\
\hline & $\begin{array}{l}\text { Aydınlatma } \\
\text { yetersizliği }\end{array}$ & 4 & 2,7 & 91,3 \\
\hline & İşyeri düzensizliği & 8 & 5,3 & 96,7 \\
\hline & Diğer & 5 & 3,3 & 100 \\
\hline & Toplam & 150 & 100 & \\
\hline
\end{tabular}

Tablo 11: Çalışma ortamında çalışanların gerekli kişisel koruyucu donanımlara sahip olması ve kullanma durumları

\begin{tabular}{|c|c|c|c|c|}
\hline \multicolumn{2}{|c|}{} & Frekans & $\begin{array}{c}\text { Yüzde } \\
(\%)\end{array}$ & $\begin{array}{c}\text { Kümülatif } \\
\text { Yüzde } \\
(\%)\end{array}$ \\
\hline \multirow{4}{*}{$\begin{array}{c}\text { KKD } \\
\text { kullanımı }\end{array}$} & Hiç & 8 & 5,3 & 5,3 \\
\cline { 2 - 5 } & Çok az & 39 & 26 & 31,3 \\
\cline { 2 - 5 } & Bazen & 45 & 30 & 61,3 \\
\cline { 2 - 5 } & Çok sık & 23 & 15,3 & 76,7 \\
\cline { 2 - 5 } & Her zaman & 35 & 23,3 & 100 \\
\cline { 2 - 5 } & Toplam & 150 & 100 & \\
\hline
\end{tabular}

Tablo 12: Dökümhanede çalışmadan kaynaklı sağlıkla ilgili en fazla şikayetler

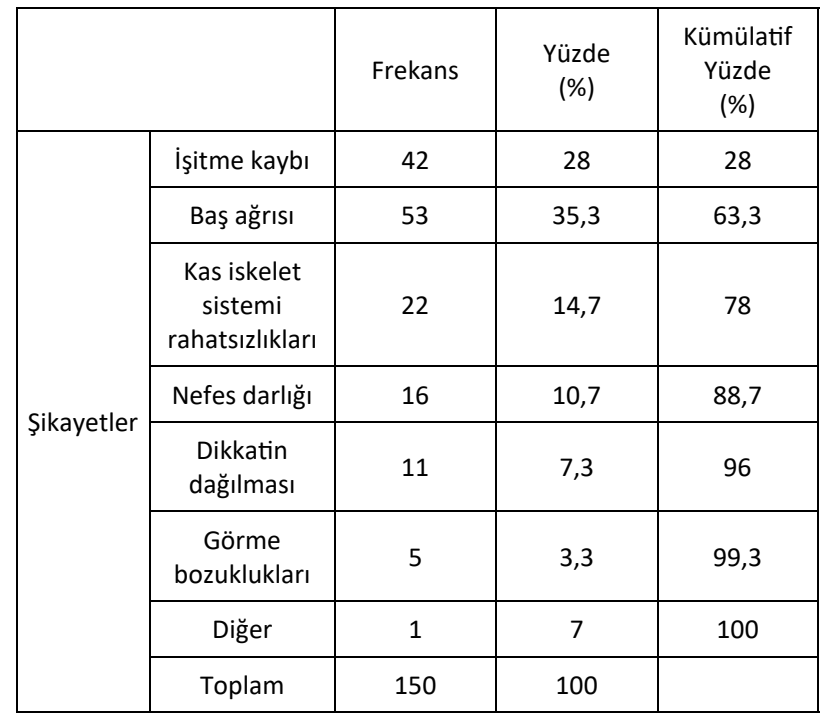


Tablo 13: Kişisel koruyucu donanımların kullanımına özen gösterilmemesinin nedeni

\begin{tabular}{|c|c|c|c|c|}
\hline & & Frekans & $\begin{array}{c}\text { Yüzde } \\
(\%)\end{array}$ & $\begin{array}{l}\text { Kümülatif } \\
\text { Yüzde } \\
(\%)\end{array}$ \\
\hline \multirow{6}{*}{$\begin{array}{c}\text { KKD } \\
\text { kullanıl- } \\
\text { masının } \\
\text { nedeni }\end{array}$} & $\begin{array}{l}\text { İşletmenin ek } \\
\text { maliyet olarak } \\
\text { görüp koruyucu } \\
\text { vermemesi }\end{array}$ & 14 & 9,3 & 9,3 \\
\hline & $\begin{array}{c}\text { Koruyucunun } \\
\text { çalışanı rahatsız } \\
\text { etmesi }\end{array}$ & 66 & 44 & 53,3 \\
\hline & $\begin{array}{l}\text { Kullanılan } \\
\text { koruyucunun işi } \\
\text { zorlaştırması }\end{array}$ & 20 & 13,3 & 66,7 \\
\hline & $\begin{array}{c}\text { Kullanılan } \\
\text { koruyucunun } \\
\text { çalışana faydası } \\
\text { olmadığı düşüncesi }\end{array}$ & 35 & 23,3 & 90 \\
\hline & Diğer & 15 & 10 & 100 \\
\hline & Toplam & 150 & 100 & \\
\hline
\end{tabular}

Tablo 14: İş sağlığı ve güvenliği eğitimi alma durumları

\begin{tabular}{|c|c|c|c|c|}
\hline \multicolumn{2}{|c|}{} & Frekans & $\begin{array}{c}\text { Yüzde } \\
(\%)\end{array}$ & $\begin{array}{c}\text { Kümülatif } \\
\text { Yüzde } \\
(\%)\end{array}$ \\
\hline \multirow{2}{*}{$\begin{array}{c}\text { Eğitim Alma } \\
\text { Durumu }\end{array}$} & Evet & 64 & 42,7 & 42,7 \\
\cline { 2 - 5 } & Hayır & 86 & 57,3 & 100 \\
\cline { 2 - 5 } & Toplam & 150 & 100 & \\
\hline
\end{tabular}

\section{TARTIŞMA}

Çalışanların demografik özellikleri arasında yaş grupları, cinsiyet, eğitim düzeyleri, çalıştıkları bölümü ve mesleki tecrübeleri sorgulanmıştır. Tablo 1'de görüldüğü gibi \% 41,3’ ü 36-45 yaş arasındaki çalışanlardan oluşmaktadır. Tablo 2'de dökümhane çalışanlarının eğitim düzeyleri yüzdelerine bakıldığında en yüksek oranda $(\% 43,3)$ orta öğretim mezunu olduğu, \%5,3 oranında ise üniversite mezunu- nun çalıştı̆̆ı görülmektedir. Dökümhane çalışanlarının büyük çoğunluğunun eğitim düzeylerinin düşük olduğu tespit edilmiştir. Tablo 3'de anket-araştırmaya katılan çalışanların \%43,3’ü döküm, \%22,7’si kalıp, \%17,3’ü maça yapımında çalışanlardan oluşturmaktadır. Tablo 4'de görüldüğü gibi anket-araştırmaya katılan dökümhane çalışanlarının \%30'unun 5 yıl, \%40'nın 5-10 yıl, \%20'sinin 15 yıl, \%6'sının 15-20 yıl, \%4’ünün 20 yıl olduğu tespit edilmiştir.

Tablo 5'de anket-araştırmasına katılan çalışanların \% 28 'i iş kazası geçirdiğini \%42,7'si bir iş kazasına şahit olduğunu ifade etmiştir. Tablo 6'da ise araştırmaya katılan dökümhane çalışanlarının \%24’ü hiçbir zaman, \%38,7’sinin ara sıra, \%10,7'si sık sık, \%25,3'ü çoğunlukla , \%1,3’ü her zaman iş kazalarının sıklığını belirtmiştir.

Tablo 7'de çalışanların çoğunluğunun iş kazasına döküm esnasında maruz kaldıkları veya görüp şahit oldukları görülmektedir. Araştırmaya katılan çalışanlar, ergimiş metal ve kıvılcım sıçraması gibi sıklıkla maruz kaldıkları ancak tedavi gerektirmeyen veya işgücü kaybına yol açmayan iş kazaları işin akışı içinde olağan olarak değerlendirmektedir.

Tablo 8'de görüldüğü gibi çalışanların çalışma ortamlarını uygun bulup bulmadıkları sorulduğunda \%54,3'ü çalıştıkları iş ortamının uygun olmadığını belirtmişlerdir.

İş güvenliği kapsamında çalışanların iş kazaları ve meslek hastalıklarına bakış açılarını değerlendirmek üzere mesleki risklerin farkındalığı, iş kazası geçirip geçirmedikleri ve iş kazalarının nedenlerine yaklaşımları değerlendirilmiştir. Dökümhane çalışanlarına göre iş kazasının nedenleri arasında kusurlu alet ve ekipman, denetim eksikliği, kişisel koruyucu donanımların uygun olmaması ve iş yükü fazlalı$\breve{g}_{1} /$ yorgunluk olarak belirtilmiştir. Anket-araştırmasına katılan dökümhane çalışanlarının iş kazalarına yol açan 


\section{2}

nedenlere bakışı Tablo 9'da verilmiştir. Bu tablodan görüldüğü gibi anket-araştırmasına katılan çalışanlar iş kazalarının nedenlerini \%28,3'ü kusurlu alet ve ekipman nedeniyle, \%12,7’si kişisel koruyucu donanımların uygun verilmemesi nedeniyle, \%18,7'si denetim yetersizliğinden, \% 11,3 ’ü iş fazlalığı/yorgunluk olarak değerlendirmiştir.

Dökümhaneler iş sağlığı ve güvenliği ile meslek hastalıkları açısından en riskli grupların arasında yer almaktadır. Dökümhane çalışanları, çalışma ortamı ve yaptıkları iş dikkate alındığında en fazla tehlikelere maruz kalan meslek gruplarını oluşturmaktadır. Araştırmada, dökümhane çalışanlarına özgü mesleki riskler ele alınıp ve iş güvenliğinin önemine değinilmiştir. Araştırmaya katılan çalışanlar Tablo 10 'da görüldüğü gibi \%32,7’si aşırı sıcaklık, \%30,7'si toz, \%15,3'ü gürültü olarak çalışma ortamını iş güvenliği açısından olumsuz yönde etkileyen faktörler olarak belirtmiştir.

Anket-araştırmasına katılan çalışanlara, kişisel koruyucu donanım kullanımına yönelik düşünceleri sorulmuştur. Çalışanların kişisel koruyucu donanımları kullanmanın gerekliliği ve önemine yönelik fikirlerinin öğrenilmesi amaçlanmıştır. Tablo 11'de görüldüğü gibi çalışanların \% 30'u bazen, \%26'sı çok az ve \%23,3'ü her zaman kişisel koruyucu donanım kullandıklarını belirtmişlerdir

Yapılan anket-araştırmasına katılan çalışanların sağlıkla ilgili en fazla şikayetleri Tablo 12'de görülmektedir. Bu şikayetler; \%35,3'ü baş ağrısı, \%14,7’si kas iskelet sistemi rahatsızlıkları ve \%10,7’si nefes darlığı olduğunu belirtmiştir. Dökümhanelerde de işlemler genellikle insan gücüne dayanılarak gerçekleştirildiğinden kas iskelet sistemi rahatsızlıkları yaşanmaktadır.

Tablo 13'de ise çalışanlar yaptıkları işte kişisel koruyucu kullanılmasına özen gösterilmemesinin nedeni olarak sırasıyla; \%44'ü kendilerini rahatsız ettiğini, \%23,3’ü ise kendisine fayda sağlamadığını düşündüğünü belirtmiştir. Çalışanlar kişisel koruyucu donanımları (baret, yüz siperi, yanmaz malzemeden yapılmış iş elbisesi, yanmaz tabanlı çelik burunlu ayakkabı, yanmaz eldiven vb.) kullanmanın işlerini aksattığı gerekçesiyle kullanmaktan kaçınmaktadırlar.

İşveren, çalışan işe başlamadan önce, çalışma yeri veya iş değişikliği, iş ekipmanının değişmesi, yeni teknolojinin uygulanması gibi durumlarda iş güvenliği eğitimleri verilmesini sağlamalıdır Dökümhane çalışanlarının iş sağlığı ve güvenliği ile ilgili eğitim alıp almadıkları hakkındaki fikirleri sorgulanmıştır. Tablo 14'de anket-araştırmaya katılan çalışanların \%57,3'ü iş güvenliği eğitimi almadığını belirtmiştir.

\section{SONUÇ}

Araştırmadan elde edilen bulgular ışığında, iş sağlığı ve güvenliği eğitimi alma oranının yüksek olmasına rağmen iş kazalarının sıklıkla yaşanması çalışanların eğitim seviyesi ile iş sağlığ1 ve güvenliği kültürünün yerleşememesinden kaynaklanmaktadır. Dökümhanelerde iş sağlığı ve güvenliğinin sağlanabilmesi için yasa ve yönetmeliklerin uygulanması, çalışanlarca iş güvenliğinin öneminin kavranması ve iş güvenliği eğitimlerine özen gösterilmesi gerekmektedir. Bu açıdan iş kazalarının önlenebilmesi için iş sağlığı ve güvenliği kültürünün işyerindeki tüm çalışanlar tarafından eksiksiz uygulanması gerekmektedir. İşverenin yükümlülüğü, işyerinde mevcut tehlikeleri belirleyerek, olası risklere karşı tedbirler alarak, işin niteliğine uygun kişisel koruyucu donanımı seçmektir. Araştırmada, çalışanların çoğunluğu kullandıkları kişisel koruyucu donanımlardan rahatsız olduğunu ve kendisine faydası olmadığını belirtmiştir. Bu nedenle uygun kişisel koruyucu seçimi için işyerinin tehlikeleri tespit edilip değerlendirilerek risk analizinin yapılma- 
sı gerekmektedir. Kişisel koruyucu donanım seçiminde dikkat edilmesi gereken en önemli özellik çalışana tam koruma sağlamasıdır. Bunun yanı sıra çalışanların uzun saatler boyunca kullanması gerektiği kişisel koruyucu donanımlar, insan sağlığına zararlı etkenlerden koruması gerektiği gibi aynı zamanda da ergonomik olmalıdır.

Araştırmaya katılan çalışanların çoğunluğu çalışma ortamlarını iş güvenliği açısından uygun bulmamıştır. Genelde iş kazası sonrasında oluşan tehlikeli durumu iyileştirme amacıyla çalışmalar yapılmaktadır. Ancak, öncelikle yapılması gereken iş kazalarını önlemek amacıyla gerekli çalışmalara yönelmektir. İş güvenliği konusunda alınması gereken önlemler için yapılan yatırımlar maliyet olarak görülmemelidir. İşs sağlığı ve güvenliği ile ilgili uyulması gereken kurallar tamamen uygulandığında iş kazaları ve meslek hastalıkları oranlarında azalma meydana gelecektir. İş güvenliği uygulamalarının uygulanıp uygulanmadığının tespit edilmesi için denetim mekanizmasının aktif olması gerekmektedir.

\section{KAYNAKLAR}

[1] Arıkoğlu Z., 1988.İşci Sağlığı ve İş Güvenliği Tanımı ve Amacı, Ç.Ş.G.B İşci ve Sağlığı ve İş Güvenliği Sempozyumu, Ankara s.3

[2] Çam, İ. (1993). “Türkiye’de İş Kazaların ve Meslek Hastalıkları Probleminin Çözümünde İş Güvenliği Eğitiminin Önemi Üzerine Bir Araştırma”. ÇSGB. İşçi Sağlığı Daire Başkanlığı Yayın No:50, S: 49-67, Ankara.

[3] Ekiz, A., 1992. Yapı Denetimi. Yapı İşlerinde İşçi Sağlığı ve İş Güvenliği TMMOB İnşaat Müh. Odası Adana Şubesi İş Güvenliği Seminer Notları.

[4] Çoban, Hatice. (2006). İş Kazaları ve Meslek Hastalıkları: Estaş ve Tüdemsaş'ta Bir Araştırma. Yüksek Lisans Tezi. Cumhuriyet Üniversitesi Sosyal Bilimler Enstitüsü. Sivas.

[5] Sosyal Güvenlik Kurumu. SGK İstatistik Yıllıkları. 2012 Yılı SGK İstatistikleri. www.sgk.gov.tr
[6] Altınel H., İşçi Sağlığı ve İş Güvenliği, Detay Yayıncılık, Ankara 2013

[7] Atlı K., Dökümhanelerde İş Sağlığı Sorunları, Türk Tabipler Birliği Mesleki Sağlık ve Güvenlik Dergisi, Nisan 2001, s.17

[8] İşyeri Bina ve Eklentilerinde Alınacak Sağlık ve Güvenlik Önlemlerine İlişkin Yönetmeliği, Resmi Gazete Sayısı:28710 Resmi Gazete Tarihi:17.07.2013, T.C Resmi Gazete, Ankara

[9] Yıldız A N, Bilir N. Sıcak Çalışma Ortamının Subjektif Olarak Değerlendirilmesi. Toplum Hekimliği Bülteni Mayıs - Ağustos 2007; Cilt 26: Sayı 2.

[10] Camkurt Mehmet Zulfi. (2007). İşyeri Çalışma Sistemi ve İsyeri Fiziksel Faktörlerin Kazaları Üzerindeki Etkisi. TÜHİS İş Hukuku ve İktisat Dergisi, 20-21 (6-1), s.94

[11] Kısa Y., Döküm,2014, Atölyelerindeki İş Sağlığı ve Güvenliği Koşullarının Çok Ölçütlü Karar Verme Yöntemleriyle Değerlendirilmesi, Ankara s.18

[12] Adaş C. G., İş Kazalarının İş Bilimsel Açıdan İncelenmesi, Yayınlanmamış Bitirme Tezi, İstanbul Teknik Üniversitesi İşletme Fakültesi, İstanbul, 1984, s.48 